\title{
5 Differential object marking and case alternation
}

The aim of this chapter is to discuss differential object marking and case alternation in Polish and the factors underlying them. In the first section, I will introduce the notion of differential object marking and what kinds of patterns we find cross-linguistically. The following two sections deal with differential object marking in Polish. Section 5.2 looks at split case alternation and section 5.3 deals with fluid case alternation. In these sections, I will focus on the question whether definiteness is responsible for the case alternation. Furthermore, I will only investigate bare NPs.

\subsection{Differential object marking}

This section on differential object marking is based on Aissen (2003) and de Swart (2007), who analyse this phenomenon cross-linguistically. To illustrate the phenomenon, de Swart starts by giving the following examples from Malayalam, a Dravidian language spoken in India:

(1) Malayalam (Dravidian; Asher \& Kumari 1997: 203, quoted after de Swart 2007: 1)

a. Avan oru pafuvin-e vanni.

he INDEF cow-ACC buy.PST

'He bought a cow.'

b. naan teenna vanni.

I coconut buy.PST

'I bought a coconut.'

As de Swart (2007: 1) observes, the sentences in (1) differ in that in (1a) the direct object pafuvine 'cow' is marked by accusative case while there 
is no case marking in (1b) with teenna 'coconut'. The different case marking of the two direct objects is motivated by the fact that the referent of the direct object in (1a) is animate whereas in (1b) it is inanimate. Only direct objects with animate referents are marked by the accusative case, but direct objects with inanimate ones are not. ${ }^{1}$ Thus the animacy of the object plays a role in Malayalam and leads to differential object marking. This case marking alternation prevents syntactic ambiguities since referents of subject arguments tend to be animate. In the case of two arguments that have animate referents and no case marking on the direct object and subject, it would be unclear which one of the two arguments is the subject (de Swart 2007: 3f., 73f.).

In Turkish, the specificity of the direct object has an influence on case marking. In (2a), the direct object is marked with the accusative case as specific while in $(2 \mathrm{~b})$ there is no marking, which results in an unspecific

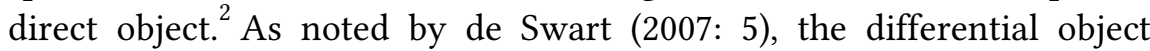
marking in Turkish cannot be attributed to the avoidance of ambiguities, but to the marking of prominent objects. ${ }^{3}$

(2) Turkish (Turkic; Kornfilt 2003: 127, quoted after de Swart 2007: 5)

a. Ahmet dün akşam pasta-yl ye-di.

Ahmet yesterday evening cake-ACC eat-PST

'Yesterday evening, Ahmet ate the cake.'

b. Ahmet dün akşam pasta ye-di.

Ahmet yesterday evening cake eat-PST

'Yesterday evening, Ahmet ate cake.'

Later on, de Swart (2007: 88f.) shows that, in certain contexts, direct objects with inanimate referents can be marked by the accusative case in Malayalam in order to avoid misinterpretations.

2

The accusative case only marks the direct object as specific if it directly precedes the verb as in (2). In other syntactic positions, the direct object must be marked by the accusative case and does not necessarily lead to a specific interpretation (Heusinger \& Kornfilt 2005: 11f.).

3

The English translations of the Turkish examples (2) given by Kornfilt (2003: 127) are misleading by using the definite article in (2a) vs. no article in (2b). They suggest that the Turkish sentences differ with respect to definiteness and not specificity. 
A similar situation can be found in Hebrew, where only definite direct objects are marked by the accusative case 'et (3a) while indefinite ones are unmarked (3b) (Aissen 2003: 453; de Swart 2007: 17f.).

(3) Hebrew (Semitic; Aissen 2003: 453)
a. Ha-seret her'a 'et-ha-milxama.
DEF-movie showed ACC-DEF-war
'The movie showed the war.'
b. Ha-seret her'a (“'et-)milxama.
DEF-movie showed ACC-war
'The movie showed a war.'

On the basis of the given examples, de Swart (2007: 5f.) argues that differential object marking can be explained as a means of avoiding ambiguities - as in Malayalam - or by the prominence of the direct object as in Hebrew and Turkish. Furthermore, he states "that animacy can only trigger the occurrence of overt case marking. Definiteness/specificity, on the other hand, can itself be determined by the occurrence of overt case marking" (de Swart 2007: 5f.). This again has to do with the fact that "[a]nimacy is an inherent (lexical) feature of noun phrases which cannot be altered by case (or any other) marking. Nouns are, by contrast, not inherently specified for definiteness or specificity, but can be marked as such by means of articles or case marking" (de Swart 2007: 6).

Spanish is an example of a language that shows an interaction of animacy and definiteness/specificity. The preposition $a$ is found with definite direct objects which have an animate referent. In (4a) and (4b), the direct objects are definite and their referents are animate and this is why the presence of $a$ is required whereas in (4c) the referent of the direct object is inanimate and thus the NP la mesa 'the table' does not allow for the combination with $a$ (Bleam 2005: 3f., de Swart 2007: 128f., 189f.). ${ }^{4}$

\footnotetext{
Direct objects referring to inanimate entities can occur with $a$ in contexts in which
} syntactic ambiguities could arise as is emphasized by de Swart (2007: 129f.). 
(4) Spanish (Romance, Indo-European)
a. Mari vió a la mujer.
Mari saw A DEF woman
'Mari saw the woman.' (Bleam 2005: 3)
b. Mari vió a-l gato.
'Mari saw the cat.' (Bleam 2005: 4)
c. Mari vió ( ${ }^{*}$ a) la mesa.
Mari saw A DEF table
'Mari saw the table.' (based on Bleam 2005: 4)

In the case of an animate referent of an indefinite direct object NP, $a$ marks the NP una mujer 'a woman' as specific (5).

(5) Spanish (Bleam 2005: 5)
Mari vió (a) una mujer.
Mari saw A INDEF woman
'Mari saw a woman.'

This shows that with definite objects animacy triggers the occurrence of $a$ whereas in the domain of indefinite objects of animate referents specificity is determined by the presence of $a$.

For the following, it is crucial to distinguish between split and fluid case alternation (cf. Dixon 1979). Fluid case alternation means that "[w]ithin one linguistic context the same noun can either be marked or not with a concomitant change in meaning" (de Swart 2007: 186). The Turkish accusative marking on direct objects represents a fluid case alternation where only specific objects are marked. The differential object marking in Malayalam which is due to animacy is an example of split case alternation since "within one linguistic context, i.e., animate nouns, case marking is obligatory, whereas it is not in another linguistic context, i.e., inanimate nouns" (de Swart 2007: 185). In the next section, two cases of split case alternation will be presented before discussing fluid case alternation in Polish in section 5.3. 


\subsection{Split case alternation}

In this section, I discuss two cases in which split case alternation is found in Polish. I will start by giving a brief overview of the Polish case system with special emphasis on the occurrence of the accusative and genitive case, referring especially to Tokarski (2001: 71f. [1973]) and Skibicki (2007: 31f.). This section also provides the basis for the discussion of information structure in chapter 6 .

\subsubsection{The Polish case system and animacy}

In Polish, we find a rich case system. Polish has seven cases, which are illustrated with the feminine noun kobieta 'woman' in table 14:

\begin{tabular}{|l|c|c|}
\cline { 2 - 3 } \multicolumn{1}{c|}{} & \multicolumn{2}{c|}{ kobieta 'woman' } \\
\cline { 2 - 3 } \multicolumn{1}{c|}{} & singular & plural \\
\hline NOM & kobieta & \multirow{2}{*}{ kobiety } \\
\hline ACC & kobiete & kobiet \\
\hline GEN & kobiety & kobietom \\
\hline DAT & \multirow{2}{*}{ kobiecie } & kobietach \\
LOC & kobieto & kobiety \\
\hline VOC & kobieta & kobietami \\
\hline INS & & \\
\hline
\end{tabular}

Table 14: Case endings of feminine nouns like kobieta 'woman' in Polish.

Feminine nouns ending in - $a$ which have inanimate referents, such as lampa 'lamp', follow the same paradigm as given in table 14 for the noun kobieta 'woman'. In contrast to English, for instance, the word order in Polish is flexible. This is shown by (6a) and (6b), in which it is not word order, as in English, but rather case marking that is responsible for indicating which NP is the subject and which is the direct object of the sentence in Polish. Although in both examples the noun Maria is at the beginning of the sentence, in (6a) it is the subject marked with nominative case whereas in (6b) it is marked with accusative case and is thus the direct object. However, syntactic relations are not always unambiguous- 
ly determined by case in Polish, which occurs, for instance, due to case syncretism. ${ }^{5}$ Feminine nouns do not have a separate accusative form in plural, but show a syncretism with the nominative. In such a case, it is word order that determines which NP is the subject and which is the direct object, as in (6c). The NP pielegniarki 'nurses' is the subject due to its sentence-initial position whereas the post-verbal NP nauczycielki 'teachers' is the direct object.

(6)
a. Mari-a bi-t-a foann-ę.
Maria-NOM beat-PST-F Joanna-ACC
'Maria beat Joanna.'
b. Mari-e bi-t-a foann-a.
Maria-ACC beat-PST-F Joanna-NOM
'Joanna beat Maria.'
c. Pielegniark-i widzia-ty nauczycielk-i.
nurse.F-PL.NOM/ACC see-PST.F.PL teacher.F-PL.NOM/ACC
'The nurses saw (the) teachers.'

With neuter nouns such as okno 'window', we observe a syncretism of the nominative, accusative, and vocative case in singular and plural. The same is true for the neuter noun dziecko 'child' in the singular. In the plural, there is one form dzieci, which is used for the nominative, accusative, vocative, and genitive case.

\begin{tabular}{|c|c|c|c|c|}
\hline Neuter & singular & Plural & singular & plural \\
\hline NOM & \multirow{3}{*}{ okno } & \multirow{3}{*}{ okna } & \multirow{3}{*}{ dziecko } & \multirow{4}{*}{ dzieci } \\
\hline $\mathrm{ACC}$ & & & & \\
\hline VOC & & & & \\
\hline GEN & okna & okien & dziecka & \\
\hline DAT & oknu & oknom & \multirow{2}{*}{ dziecku } & dzieciom \\
\hline LOC & oknie & oknach & & dzieciach \\
\hline INS & oknem & oknami & dzieckiem & dziećmi \\
\hline
\end{tabular}

Table 15: Case endings of neuter nouns like okno 'window' and dziecko 'child' in Polish. 
Table 16 demonstrates that masculine nouns behave differently depending on whether their referent is animate or not, which is not the case with neuter and feminine nouns. For singular masculine nouns, it can be observed that if the referent is inanimate, as in the case of dom 'house', we have a syncretism of the accusative with the nominative case, which is also found with neuter nouns. However, if the referent is animate, the accusative coincides with the genitive case like with ptak 'bird'. In plural, only with nouns which have human referents we find a syncretism of the accusative and genitive case. For all other referents (inanimate or animate but not human), the accusative coincides with the nominative.

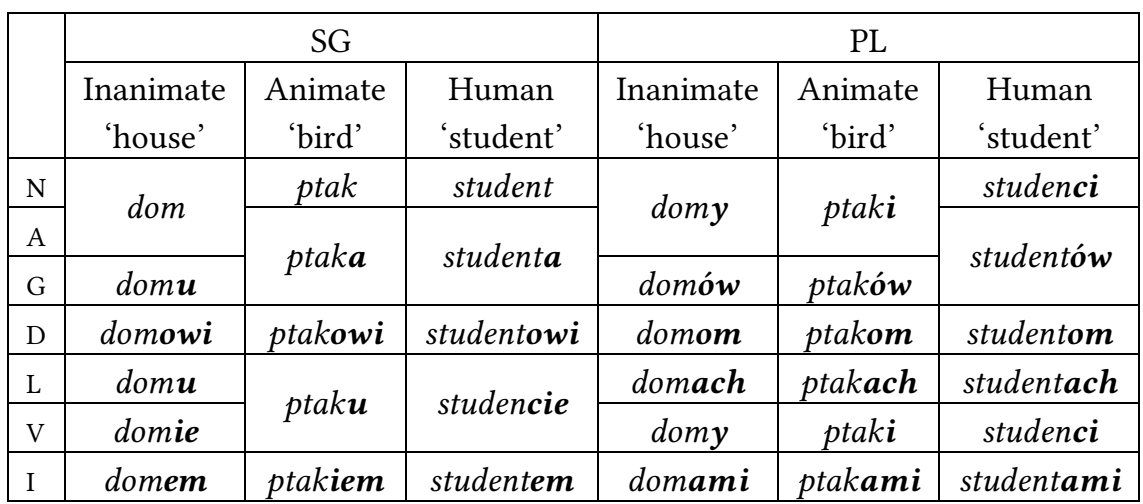

Table 16: Case endings of masculine nouns like dom/ptak/student in Polish.

The different treatment of the nouns in table 16 is similar to the situation presented for Malayalam, where animacy also triggers differential object marking. However, in Polish we find this alternation only in the domain of masculine nouns in order to explicitly mark what the subject and what the direct object is and thus to avoid syntactic ambiguities. ${ }^{6}$ With-

There are some classes of masculine nouns in Polish which do not have animate referents, but still require the genitive case as direct objects in singular. Most of them are names and thus ICs such as names for dances like krakowiak 'Cracovienne', polonez 'polonaise', currencies like dolar 'dollar', funt 'pound', brands of cars like trabant 'Trabant', fiat 'Fiat' and cigarettes like sport, giewont, wawel, names for fungi grzyb 'mushroom', maślak 'boletus', names for viruses and bacteria wirus 'virus', bakcyl 'bacterium'. Further examples are names for corpse 
out the case marking on ptak 'bird' in (7a) it would be unclear whether Jan saw the bird or the other way around. This kind of ambiguity does not arise with 'house'. With masculine nouns in plural, the split is only observable with human referents. For nouns with inanimate and nonhuman animate referents, there is a syncretism of the nominative and accusative case (7b).
a. Jan widziat dom
Jan see.PST.SG house.SG.ACC|NOM
/ ptak-a.
'Jan saw a/the house/a/the bird.'
b. Oni widzieli dom-y
they see.PST.PL house-PL.ACC|NOM student-ów.
bird-SG.ACC|GEN
/ ptak-I
student-PL.ACC|GEN
'They saw (the) houses/(the) birds/(the) students.'

With feminine nouns in the singular all direct objects are marked by a separate accusative form. However, this is not the case with feminine nouns in plural. With neuter nouns, there is no direct object marking split observable either. Almost all referents of neuter nouns are inanimate in Polish and no syntactic ambiguities could arise. There are only a few exceptions such as the neuter noun dziecko 'child' whose referent is animate (see table 15).

As was shown in Polish, the different marking of the object is triggered by the animacy of the referent of singular masculine nouns and by humanness of plural masculine nouns. This is a property of the noun's referent and the differential object marking does not interfere with definiteness, which is a property of NPs. As example (7) shows, there is no difference in definiteness between house and bird. Both NPs can receive a definite or indefinite reading. In (7), only masculine sortal concepts are presented. In the examples in (8), INs (8a) and FNs (8b) are used to show that masculine animate and masculine inanimate nouns in singular do

trup 'corpse', topielec 'drowned person', wisielec 'hanged person' (see Tokarski 2001: 85 [1973], Nagórko 2006: 143) and some fruits/vegetables banan 'banana', pomidor 'tomato', ziemniak 'potato'. For a more detailed description of these exceptions see Grappin (1951) and Wierzbicka (1988: 447f.). 
not differ with regard to definiteness, but only have a definite interpretation. With RNs (8c), in general a definite and indefinite interpretation is possible. This shows that differential case marking does not interfere with $[ \pm \mathrm{U}]$ concept types.

a. IN

Jan widziat księżyc / papież-a.

Jan saw moon.M.ACC|NOM Pope-M.ACC|GEN

'Jan saw the moon/the Pope.'

b. FN

fan widziat nos Ann-y / ojca

Jan saw nose.M.ACC|NOM Anna-GEN father.M.ACC|GEN

Ann-y.

Anna-GEN

'Jan saw Anna's nose/Anna's father.'

c. $\mathrm{RN}$

Jan widziat palec Ann-y /

Jan saw finger.M.ACC|NOM Anna-GEN

brat-a Ann-y.

brother-M.ACC|GEN Anna-GEN

'Jan saw a/the finger of Anna/ a/the brother of Anna.'

In Polish, there is also a group of verbs which requires all direct objects to be in genitive case. ${ }^{7}$ Such verbs are, for example, verbs expressing desire or need (życzyć 'wish', chcieć 'want', potrzebować 'need', szukać 'look for'), some reflexive verbs (bać się 'be afraid of', uczyć się 'learn'), verbs expressing emotions (nienawidzieć 'hate'), and verbs expressing negative meaning (zakazywać 'forbid') (Fisiak et al. 1978: 65). ${ }^{8}$ In (9), the three genitive objects show that the genitive case does not only allow for an indefinite reading of the NPs.

\footnotetext{
$7 \quad$ Verbs which require a genitive object are also found in other Slavic languages. However, the Slavic languages differ in the number of such verbs and the question of obligatoriness. For a Slavic comparison see Kagan (2013: 15ff.).

For a detailed description of the verb groups that require all direct object in genitive case see Engel et al. (1999: 235f.), Błaszczak (2001: 61, note 38), and Skibicki (2007: $32)$.
} 
(9)

Jan szuka mieszkani-a $/$ ulic-y
Jan look_for.PRS flat-GEN
street-GEN Warszawskiej/
swoj-ego klucz-a.
his-GEN key-GEN
'Jan is looking for a/the flat/Warsaw street/his key.'

For some of these verbs, Fisiak et al. (1978: 85, n. 8) mention that "in colloquial Polish genitive alternates with accusative" exist such as with potrzebować 'need' and szukać 'look for', which is also observed by Buttler et al. (1971: 305). The results of my questionnaire support this observation showing that for potrzebowac the combination with accusative and genitive objects are equally accepted by most speakers. Direct objects in genitive case with szukać are accepted by all speakers, whereas only half of my informants accept the direct object in accusative case.

\subsubsection{Negation}

Negation is another factor which triggers differential object marking. Polish is well known for the fact that the genitive case is obligatory with direct objects of negated sentences such as in (10b) instead of the accusative in affirmative sentences ${ }^{9}(10 \mathrm{a})$. It is interesting to observe that the direct objects in (10a) as well as (10b) can have a definite or indefinite interpretation and that the factor for the alternation is determined by negation and not by definiteness.
a. Widze dziewczyn-ę. see.1SG girl-SG.ACC
'I see a/the girl.'
b. Nie widze dziewczyn-y / ("dziewczyn-ę). NEG see.1SG girl-SG.GEN girl-SG.ACC 'I do not see a/the girl.'

As mentioned at the end of the previous section, there are also verbs which always require the direct object in genitive case independent of the presence of negation. For a detailed analysis of negation in Polish see Błaszczak (2001). Furthermore, Harrer-Pisarkowa (1959) gives a diachronic analysis of the distribution of accusative and genitive objects in negated sentences in Polish. 
With the bare IN Maria in (11) and the FN matka 'mother' in (12), we get a definite reading in affirmative and negated sentences if not marked explicitly as indefinite. With the RN siostra 'sister' (13), the NP allows for a definite or indefinite reading. Only feminine nouns are used in the examples in order to provide a morphological distinction between the accusative and genitive cases:
a. Widze Mari-ę. see.1SG Maria-ACC 'I see Maria.'
b. Nie widze Mari-i / ( ${ }^{*}$ Mari-e).
NEG see.1SG Maria-GEN Maria-ACC
'I do not see Maria.'
a. Widze matk-e Mari-i. see.1SG mother-ACC Maria-GEN 'I see Maria's mother.'
b. Nie widze matk-i Mari-i.
NEG see.1SG mother-GEN Maria-GEN
'I do not see Maria's mother.'
a. Widze siostr-e Mari-i. see.1SG sister-ACC Maria-GEN 'I see a/the sister of Maria.'
b. Nie widze siostr-y Mari-i. NEG see.1SG sister-GEN Maria-GEN 'I do not see a/the sister of Maria.'

In Upper Silesian, just like in standard Polish, the genitive of negation is obligatory (14). 
Upper Silesian
a. Widza dziotch-a. see.1SG girl-SG.ACC 'I see a girl.'
b. Niy widza dziotch-y / (*dziotch-a). NEG see.1SG girl-SG.GEN girl-SG.ACC 'I do not see a girl.'

In Russian, in contrast to Polish and Upper Silesian, the direct object in negated sentences can be marked by genitive or accusative case, resulting in a fluid case alternation (15):

Russian (Timberlake 1986: 342)

a. Ja ne našel cvet-y.

I NEG found flower-PL.ACC

'I did not find the flowers.'

b. Ja ne našel cvet-ow.

I NEG found flower-PL.GEN

'I did not find any flowers.'

According to Timberlake (1986), "the accusative in the plural example above [15] would be used most naturally in a definite sense [...], while the genitive would be used in an indefinite sense" (Timberlake 1986: 342), which is also confirmed by my Russian informants. This topic has been focused on during previous decades and there are many authors who have investigated Russian examples such as in (15). Kagan (2013), among others, argues that there are several properties of the direct object which influence the choice of the case such as abstract vs. concrete noun, the number of the noun, definiteness, specificity, proper vs. common noun (Kagan 2013: 10ff.). With respect to definiteness, she says that the "genitive is more likely to be assigned to indefinite objects than to definite ones" (Kagan 2013: 12). For further literature on this topic, see Partee \& Borschev (2007), Kagan (2013) and the literature cited therein.

Czech represents another extreme, since in negated sentences the direct object is usually in accusative case and the genitive case is regarded as archaic (Franks \& Dziwirek 1993: 294f., Short 1993: 511, Janda \& 
Townsend 2000: 69, Mendoza 2004: 230), although the genitive case was the normal case for the direct objects of negated sentences in Old Czech (Short 1993: 511). In Serbo-Croatian, the genitive of negation is also no longer productive (16), according to Franks (1995: 205): ${ }^{10}$

(16) Serbo-Croatian (Franks 1995: 207)
a. nisam čitao nijedan časopis
NEG.AUX.1SG read.M.SG not_even_one.ACC magazine.ACC 'I didn't read even one magazine'
b. "nisam čitao nijednog časopisa NEG.AUX.1SG read.M.SG not_even_one.GEN magazine.GEN

This brief comparison shows that there are significant differences between the Slavic languages concerning the choice of case for direct objects of negated sentences and that, for instance, in Russian this also interacts with definiteness.

\subsubsection{Summary}

In section 5.2, I have shown that the case alternation is triggered by animacy/humanness and negation in Polish. Here, definiteness does not play a role since the direct objects can receive a definite or indefinite interpretation. Table 17 which summarizes the results reveal that accusative and genitive objects can get a definite or indefinite reading. The table also shows that inherently unique concept types are interpreted as definite if used as bare NPs.

In Slovenian, the genitive of negation is obligatory in contrast to Serbo-Croatian (Franks 1995: 207). 


\begin{tabular}{|c|c|c|c|c|}
\hline & \multicolumn{2}{|c|}{ [-U] concepts } & \multicolumn{2}{|c|}{$[+\mathrm{U}]$ concepts } \\
\hline & $\begin{array}{l}\mathrm{ACC} / \\
\mathrm{NOM}\end{array}$ & GEN & $\begin{array}{l}\text { ACC/ } \\
\text { NOM }\end{array}$ & GEN \\
\hline $\begin{array}{l}\text { Masc. SG nouns with } \\
\text { animate referents/ } \\
\text { Masc. PL nouns with } \\
\text { human referents }\end{array}$ & - & $\begin{array}{l}\text { definite/ } \\
\text { indefinite }\end{array}$ & - & definite \\
\hline $\begin{array}{l}\text { Masc. SG nouns with } \\
\text { inanimate referents/ } \\
\text { Masc. PL nouns with } \\
\text { non-human referents }\end{array}$ & $\begin{array}{l}\text { definite/ } \\
\text { indefinite }\end{array}$ & - & definite & - \\
\hline Sentence negation & - & $\begin{array}{l}\text { definite/ } \\
\text { indefinite }\end{array}$ & - & definite \\
\hline
\end{tabular}

Table 17: Split case alternations in Polish and their interaction with the definiteness of direct objects.

\subsection{Fluid case alternation}

In the following subsections, there are three main points of investigation. The first deals with the question as to where we really find a fluid case alternation in Polish. The case alternation between accusative and genitive is very restricted. I will present two classes of verbs which are said to allow for a case alternation: (i) verbs of giving and taking and (ii) the two strictly incremental theme verbs eat and drink. These two groups of verbs are often classed together. As I showed in the previous chapter on aspect, incremental theme verbs behave differently from verbs of giving and taking with respect to definiteness. For this reason, I will discuss them separately here. The second question has to do with whether the case alternation can be attributed to definiteness or to other factors. I will show that there is a difference in definiteness between accusative and genitive direct objects. This is an effect of the partitive function of the genitive case. What partitivity is will be discussed in the next section. The third point deals with the question as to whether the four concept types distinguished by Löbner play a role. 
One remark has to be made concerning the Polish examples cited in this section. The translations of the examples are taken from the cited authors and are not my own. Sometimes the translations are in German and in such cases I translated the German sentences into English not changing the definiteness of the direct object. The translations of the authors are a crucial point, which will be discussed later.

\subsubsection{Verbs of giving and taking}

In this section, I discuss verbs such as kupić 'buy', sprzedać 'sell', brać 'take', przynieść 'bring', dać 'give', podać 'pass', dostać 'get', and pożyczyć 'lend/borrow', most of which are found in Levin's (1993:138) class of 'Verbs of Change of Possession'. ${ }^{11}$ For these verbs, it is often argued that they allow for a fluid case alternation (Bystron 1893: 24, Kempf 1970, Buttler et al. 1971: 310, Laskowski 1972: 55, Lesz 1973, Brooks 1975: 379, Fisiak et al. 1978: 69, Topolińska 1981: 83, 1984: 316f., Franks \& Dziwirek 1993: 289, Tokarski 2001: 72 [1973], and Rozwadowska \& Willim 2004: 132f.), which is illustrated by the examples in $(17)^{12.13}$
a. Kupi-t-am ${ }^{\mathrm{PF}}$ chleb
buy-PST-1SG bread.ACC
'I bought the bread'
b. Kupi-t-am ${ }^{\mathrm{PF}}$ chleb-a
buy-PST-1SG bread-GEN
'I bought some bread'
(Franks \& Dziwirek 1993: 289)

\footnotetext{
11 Lesz (1973: 64f.) calls such verbs 'verba dandi and accipiendi'.

12 It is not clear from the translations in (17) whether the direct object is used as a mass or count noun. Furthermore, the given translation of the direct object in (17) is not the only possible one. In (17a), chleb can also be translated as 'bread' or 'a bread'. In (17b), chleba can also be translated as 'bread' or 'some of the bread'. The possible interpretations of the direct objects in (17) will be discussed in more detail later in this section.

The total number of my informants for the questionnaire on case alternation was 54. Only 12 informants judged the sentence with the genitive object in (17b) as felicitous. The acceptability of such sentences will be discussed later in more detail.
} 
The case alternation as in (17) is only observable with mass and plural nouns (Laskowski 1972: 55; Sadziński 1991: 155, 1995/96: 49, 88; Rozwadowska \& Willim 2004: 133). Singular count nouns in genitive case are ungrammatical (18a) and the alternation is also restricted to perfective verbs (18b)

$$
\begin{array}{ll}
\text { a. } & \text { *Kupi-t-am }{ }^{\mathrm{PF}} \text { jabtk- } a . \\
& \text { buy-PST-1SG apple-SG.GEN } \\
\text { b. } \quad{ }^{*} \text { Kupowa-t- } a m^{\mathrm{IMPF}} \quad \text { chleb- } a \\
\\
\text { buy.IMPF-PST-1SG bread-GEN }
\end{array}
$$

Some authors like Bystroń (1893: 25), Kempf (1970: 190f.), Buttler et al. (1971: 318), Laskowski (1972: 55), Lesz (1973: 62, 64, 69), Fisiak et al. 1978: 86, n. 11, Wierzbicka (1988: 448f.), and Tokarski (2001: 73 [1973]) argue that singular count nouns allow for a case alternation. The direct object in genitive case is said to signal that the speaker only wants to have the knife in (19) for a short period of time in contrast to the accusative case. ${ }^{14}$ However, sentence (19b) is not accepted by almost all of my informants due to the genitive direct object, which is contrary to Reiter (1977: 360), who takes it to be grammatical. Furthermore, the NP nó $\dot{z}$ 'knife' in (19a) can also have an indefinite reading, contrary to Reiter.

$$
\begin{aligned}
& \text { a. } D a j^{\mathrm{PF}} m i \text { nó } \dot{z} \text {. } \\
& \text { give.IMP me knife.ACC } \\
& \text { 'Give me the/a knife.' } \\
& \text { b. }{ }^{*} D a{ }^{\mathrm{PF}} \quad m i \quad n o \dot{z}-a \text {. } \\
& \text { give.IMP me knife-GEN }
\end{aligned}
$$

After having presented what is claimed in the literature with respect to the possible fluid case alternation, the question arises with which of these verbs do we really find a case alternation? The work with my in-

$14 \quad$ The same is argued for similar constructions mentioned by Lesz (1973: 64) such as pożyczyć ołówka 'to borrow/lend pencil' or dobyć miecza 'to draw a sword'. In my investigation, it turned out that the verb dobyć is equally accepted with a genitive and accusative object. With pożyczyć, there is a strong tendency for the accusative case especially with count nouns as direct objects. With mass nouns, half of my informants allow a genitive object. 
formants clearly shows that the case alternation as in (17) is falling out of use. For instance, the genitive direct object in (17b) is regarded as highly odd by about $80 \%$ of my informants.

My observation that the genitive case is being replaced by the accusative is supported by earlier analyses carried out by Kempf (1970: 193f.), Buttler et al. (1971: 304ff.), and Lesz (1973: 71). Lesz (1973: 64f.) notes that in her questionnaire the informants prefer the accusative case especially in the colloquial speech of the young generation, too. In $79 \%$ of cases, her informants chose the accusative and only $15 \%$ the genitive case, which shows a strong dominance of the accusative case. Also Rozwadowska \& Willim (2004: 132, note 12) emphasize that there is interspeaker variation concerning the acceptability of genitive objects.

We can turn now to the question as to how definiteness is connected to case alternation. Examples such as (17) suggest that NPs marked by the accusative case in Polish correspond to definiteness while the genitive case is connected to indefiniteness. This is explicitly claimed or repeated by authors such as Sadziński (1977: 41, 1991: 155, 1995/96: 48f., 86), Piskorz (2011: 159), and Witwicka-Iwanowska (2012: 35). In (20a), the accusative is said to lead to a definite reading of the direct object whereas the genitive case in (20b) leads to an indefinite reading.
a. Kupiec kupi- $t^{\mathrm{PF}}$ mąk-ę.
merchant buy-PST flour-ACC
'The merchant bought the flour'
b. Kupiec kupi-t $t^{\mathrm{PF}}$ qqk-i.
merchant buy-PST flour-GEN
'The merchant bought flour'
(Sadziński 1995/6: 49)

However, this assumption is only partially correct, a fact which has to do with a wrong and misleading translation of the examples given above. The accusative object in (20a) can have a definite or indefinite reading whereas in $(20 \mathrm{~b})$ the genitive object is indefinite, as a result of the partitive genitive. Piñón (2003) points out that "the partitive genitive in Polish refers to proper parts of some object(s), essentially equivalent to some of the $x$ in English" (Piñón 2003: 389). This means that the NP 
marked by the genitive case expresses partitivity. Koptjevskaja-Tamm (2001b) defines partitivity as the "selection of a subset from a [definite] superset" (Koptjevskaja-Tamm 2001b: 527), which is illustrated in (21). The NP that good tea refers to the superset and some part of it is selected by some of. Due to the fact that the selected subset is indefinite, the whole partitive NP is indefinite (Löbner 2011: 291).

some of that good tea (Koptjevskaja-Tamm 2001b: 527)

An example of a partitive NP in Polish is given in (22) reflected in the first reading of the Polish sentence given in (i). However, it has to be emphasized that (22) can also have a second reading, namely a pseudopartitive one given in the second translation (ii).

$$
\begin{aligned}
& \text { Dat-em }^{\mathrm{PF}} m u \quad z u p-y . \\
& \text { gave-1SG PRON.DAT.3SG soup-GEN } \\
& \text { (i) 'I gave him some of the soup.' } \\
& \text { (ii) 'I gave him (some) soup.' }
\end{aligned}
$$

In contrast to partitive constructions, pseudo-partitive constructions do not express a selected subset from a given superset but only "an AMOUNT of some substance" (Koptjevskaja-Tamm 2001b: 523). ${ }^{15}$ Thus, with pseudo-partitive constructions we have an unspecified quantity and no given superset. This is exactly what is expressed in the second reading in (22), which is also observed by Rozwadowska \& Willim (2004: 125, 136, 139) for Polish. ${ }^{16}$

In contrast to the partitive genitive, accusative objects can have a definite or indefinite reading, as in (23).

$$
\begin{aligned}
& \text { Dat-em }^{\mathrm{PF}} m u \quad z u p-e . \\
& \text { gave-1SG PRON.DAT.3SG soup-ACC } \\
& \text { 'I gave him (the) soup.' }
\end{aligned}
$$

For a detailed analysis of partitive and pseudo-partitive constructions in the Circum-Baltic languages see Koptjevskaja-Tamm (2001b).

16 For Rozwadowska \& Willim (2004: 136f.), Polish examples like (22) cannot have a partitive reading as claimed by Piñón (2003), but only a pseudo-partitive one. I argue that both interpretations are possible depending on the context. The superset can, for instance, be provided by the context. 
So far, I have shown that for Polish the accusative object can be definite or indefinite and the partitive genitive marking leads to an indefinite reading of the direct object. The partitive genitive is restricted to perfective verbs of giving and taking and mass or plural nouns as direct objects.

Now I want to show that the acceptability of genitive objects varies from example to example depending on the verb and the direct object. The combination of the verb dać 'give' with the genitive object cukier 'sugar' in (24a) is judged by 17 of 54 informants as highly odd in contrast to the genitive object maka 'flour' with the same verb dać 'give', which was highly odd for 26 of 54 informants. With the verbs sprzedać 'sell' or kupic 'buy' the genitive object is accepted by even fewer informants. Example (20b), with the verb kupić 'buy' and the genitive object maka 'flour', is considered by 44 of 54 informants as highly odd. The reasons for the different acceptability are unclear. In order to make sure that there were no other factors which might affect the acceptability of the considered sentences, the questionnaire also included the same sentences with accusative objects. These sentences with an accusative object were felicitous for all informants, with the exception of one informant who regarded the sentence (24a) as odd due to some unknown reason.
a. Daj mi cukru- nie pijam gorzk-iej give.IMP me sugar.GEN NEG drink.1SG.PRS bitter-GEN herbat- $y$. tea-GEN

'Give me some (of the) sugar - I do not drink bitter tea.'

b. Jeśli chcesz mi pomóc, to daj mi if want.2SG.PRS me help.INF then give.IMP me $m a k-i$.

flour-GEN

'If you want to help me, then give me some (of the) flour.'

Now the question could arise what about other Slavic languages. Do they behave like Polish or do we find a totally different picture? For Russian, Steube \& Späth (1999: 157) make similar observations as I do for Polish. The Russian example (25a) shows that the direct object in the 
accusative case can have a definite or indefinite reading and the genitive case can have a partitive and pseudo-partitive reading $(25 \mathrm{~b}) .^{17}$

(25) Russian (Steube \& Späth 1999: 157)
a. Daj ${ }^{\mathrm{PF}}$ mne $x l e b$. give.IMP me bread.ACC
'Give me a/the bread.'
b. $D a j^{\mathrm{PF}}$ mne xleb-a. give.IMP me bread-GEN
'Give me some (of the) bread.'

Similarly to Polish, singular count nouns in Russian cannot be used with the partitive genitive (26a). Furthermore, due to other restrictions not all nouns can be marked with the partitive genitive (26b); some lead to ungrammatical constructions, according to Kagan (2013: 4f.).
Russian (Kagan 2013: 4f.)
a. ${ }^{*} \mathrm{Fa} \mathrm{kupil}$ (t)be jabloka.
I bought you.DAT apple.SG.GEN
'I bought an apple for you.'
b. ' *a kupil tebe knig.
I bought you.DAT book.PL.GEN
'I bought some books for you.'

Franks (1995: 207) shows that the partitive genitive is also productive for Serbo-Croatian (27). ${ }^{18}$

17 For Kagan (2013: 3), the partitive genitive does not seem to have a partitive reading, but only a pseudo-partitive one in Russian (i):
(i) a. fa kupil ${ }^{\mathrm{PF}}$ tebe jabloki.
I bought you.DAT apples.PL.ACC
'I bought (the) apples for you.'
b. Fa kupil ${ }^{\mathrm{PF}}$ tebe jablok.
I bought you.DAT apples.PL.GEN
'I bought you some apples.'
(Kagan 2013: 3)


(27) Serbo-Croatian (Franks 1995: 207)

daj mi sira, mesa $i$ vode

give me.DAT cheese.GEN meat.GEN and water.GEN

'give me some cheese, meat, and water'

Still, the partitive genitive is more restricted in Polish than in Russian. According to Filip (p.c.), the genitive case in Czech is odd and obsolete in Bohemia, but still in use in Eastern Moravia ${ }^{19}$ (28).

$$
\begin{aligned}
& \text { Czech (Filip, p.c.) } \\
& \text { Dej mi ?cukru a ?vody } \\
& \text { give.IMP me } \\
& \text { sugar.GEN and water.GEN }
\end{aligned}
$$

'Give me some sugar and water'

In the Upper Silesian dialect, many verbs of giving and taking are highly odd with genitive objects (29a). The verb dać can be combined with a direct object which is marked by the partitive genitive; however, this is not true for all direct objects (29b). (29c) shows that there are also other verbs for which a case alternation is available.

(29) Upper Silesian

a. ??Łon kupiot / sprzedot / wzion monk-i. he bought sold took flour-GEN 'He bought/sold/took some flour.'

b. Dej mi cukru / monk-i / cukerk-ów/ give.IMP me sugar.GEN flour-GEN sweet-PL.GEN *jabek. apple.PL.GEN

'Give me some sugar/flour/sweets.'

c. Łon mi przinios wod-y. he me brought water-GEN 'He brought me some water.'

19 The western and central territories of the Czech Republic are part of Bohemia while the eastern territory is part of Moravia. Standard Czech is based on the languages spoken in Bohemia (Janda \& Townsend 2000: 2f.). The different varieties of Czech and the question of standard Czech is very complex and a comprehensive discussion is given by Bermel (2000). 
The last question to be addressed here is whether the concept types play a role. It is difficult to answer this question since the referents of the direct objects in such constructions are often things to eat and drink or represent other sortal concepts. Furthermore, in the previous chapter I already discussed the difficulty of determining whether a mass noun is a $[+\mathrm{U}]$ concept. Löbner (p.c.) assumes that blood is an RN and skin an FN. There seem to be no examples of INs which could be used as direct objects such as in (30). What is demonstrated in (30a) is that the assumed $\mathrm{RN}$ krew 'blood' is interpreted as definite in the accusative case whereas in the genitive case the $\mathrm{RN}$ gets an indefinite reading. The genitive object is not accepted by all of my informants, which is indicated by the question mark. In (30b), the assumed FN skóra 'skin' only has a definite interpretation in accusative case and the genitive object is not accepted by my informants.

$$
\begin{aligned}
& \text { a. Dosta-t-em }{ }^{\mathrm{PF}} \text { krew / (?krwi) moj-ej siostr-y. } \\
& \text { get-PST-1SG blood.ACC blood.GEN my-GEN sister-GEN } \\
& \text { 'I got my sister's blood/(some) of my sister's blood.' } \\
& \text { b. Sprzeda-t-em }{ }^{\mathrm{PF}} \text { skór-e / ("skór-y) moj-ego tygrys-a. } \\
& \text { sell-PST-1SG skin-ACC skin-GEN my-GEN tiger-GEN } \\
& \text { 'I sold the skin of my tiger.' }
\end{aligned}
$$

\subsubsection{The incremental theme verbs eat and drink}

With the strictly incremental theme verbs eat and drink in Polish, we find a similar situation as with the verbs in the previous section. Authors such as Wierzbicka (1967: 2238), Engel et al. (1999: 233f.), and WitwickaIwanowska (2012: 176) claim that there is a fluid alternation available between the accusative and genitive cases. (31a) shows that a bare mass noun in accusative is interpreted as definite if combined with a perfective strictly incremental theme verb. This has already been shown in the chapter on aspect, but this is a difference to the verbs of the previous section where the accusative object of a perfective verb of giving and taking can receive a definite interpretation or not depending on the context. In (31b), the genitive object has only an indefinite reading due to 
the (pseudo-)partitive interpretation. ${ }^{20}$ Hence, we have a contrast in definiteness between (31a) and (31b) caused by the case alternation. ${ }^{21}$ However, the construction in (31b) is only accepted by about $25 \%$ of my informants, which shows that the partitive genitive also seems to be falling out of use with strictly incremental theme verbs. With an imperfective strictly incremental theme verb, the accusative object allows for a definite and indefinite reading (31c) and a genitive object is regarded as ungrammatical (31d). Also the combination of a perfective strictly incremental theme verb with a singular count noun in genitive case is ungrammatical (31e).

\begin{tabular}{|c|c|c|}
\hline$(31)$ & Perfective verb & Imperfective verb \\
\hline ACC & $\begin{array}{l}\text { a. } W y \text {-pit-em }{ }^{\mathrm{PF}} \quad \text { mlek-o. } \\
\text { WY-drank-1SG milk-ACC } \\
\text { 'I drank the milk.' }\end{array}$ & $\begin{array}{ll}\text { c. } & \text { Pit-em }{ }^{\mathrm{IMPF}} \quad \text { mlek-o. } \\
& \text { drank-1SG milk-ACC } \\
& \text { 'I was drinking (the) milk.' }\end{array}$ \\
\hline \multirow[t]{2}{*}{ GEN } & $\begin{array}{l}\text { b. ?Wy-pit-em }{ }^{\mathrm{PF}} \quad \text { mlek-a. } \\
\text { WY-drank-1SG milk-GEN } \\
\text { 'I drank some (of the) milk.' }\end{array}$ & $\begin{array}{cc}\text { d. } \quad{ }^{*} \text { Pit-em }{ }^{\text {IMPF }} \quad \text { mlek- } a . \\
\text { drank-1SG } & \text { milk-GEN }\end{array}$ \\
\hline & $\begin{aligned} \text { e. }{ }^{*} Z \text {-jadt-em }{ }^{\mathrm{PF}} & \text { jabtk-a. } \\
\text { Z-ate-1SG } & \text { apple-SG.GEN }\end{aligned}$ & \\
\hline
\end{tabular}

Here again, I would like to check whether concept types are sensitive to these constructions in Polish. However, similar problems arise as in the previous section. The examples in (32) reveal that again only a definite interpretation is possible with the accusative object. Having the $\mathrm{RN}$ as the genitive object in (32a) is considered by $25 \%$ of my informants as acceptable, whereas the genitive object with the FN in (32b) is regarded as ungrammatical. Again, I was not able to find any INs which could enter this construction.

\footnotetext{
20 For Piñón (2003: 389), only a partitive reading is possible and for Rozwadowska \& Willim (2004) only a pseudo-partitive one.

21 The sentences in (31a) and (31b) also differ with respect to (a)telicity. The accusative object in (31a) leads to a telic predication since a time span adverbial, such as $w$ minute 'in a minute', can be added. The combination of the genitive object with a time span adverbial is incompatible showing its atelicity.
} 


$$
\begin{array}{lllll}
\text { a. } & \text { Wampir } w y-p i-t^{\mathrm{PF}} & \text { krew } & \text { / (?krwi) } & \text { swoj-ej } \\
\text { vampire WY-drink-PST } & \text { blood.ACC } & \text { blood.GEN } & \text { his-GEN } \\
\text { ofiar-y. } & & & & \\
\text { victim-GEN } &
\end{array}
$$

'The vampire drank his victim's blood/(some) of his victim's blood.'
b. Z-jadt-em ${ }^{\mathrm{PF}}$ skór-ę / (" skór-y) tej ryb-y.
Z-eat.PST-1SG skin-ACC skin-GEN DEM fish-GEN
'I ate the skin of this fish.'

It is interesting to observe Slavic variation in the distribution of the partitive genitive. In contrast to Polish, in Russian the perfective verb with a

\begin{tabular}{|c|c|c|}
\hline (33) & Perfective verb & Imperfective verb \\
\hline ACC & $\begin{array}{ll}\text { a. } f a v y-p i l^{\mathrm{PF}} & \text { vod-u. } \\
\text { I VY-drink.PST } & \text { water-ACC } \\
\text { 'I drank the water.' }\end{array}$ & $\begin{array}{l}\text { c. } 7 a \text { pil }^{\mathrm{IMPF}} \quad \text { vod-u. } \\
\text { I drink.PST water-ACC } \\
\text { 'I drank/was drinking } \\
\text { (the) water.' }\end{array}$ \\
\hline GEN & $\begin{array}{ll}\text { b. } f a v y-p i l^{\mathrm{PF}} & \text { vod-y. } \\
\text { I VY-drink.PST } & \text { water-GEN } \\
\text { 'I drank some water.' }\end{array}$ & $\begin{array}{rll}\text { d. }{ }^{*} f a & p i l^{\mathrm{IMPF}} & \text { vod }-y . \\
\mathrm{I} & \text { drink.PST } & \text { water-GEN }\end{array}$ \\
\hline
\end{tabular}
genitive object is totally acceptable (33b). In Russian, we find the same picture as in Polish with only one difference. According to Kagan (2013: 3), (33b) only allows for a pseudo-partitive reading.

(Kagan 2013: 3, 5)

Also in Russian, the partitive genitive cannot be used with singular count nouns as direct objects $(34 a)^{22}$. Even if the verb is perfective and the direct object is not a singular count noun, there are restrictions for the use of the partitive genitive (34b) (Kagan 2013: 4f.).

$22 \quad$ Example (34a) is my own. 

a. “Fa s' el $l^{\mathrm{PF}}$ jabloka.
I ate apple.SG.GEN
b. $\quad{ }^{*} \mathrm{Fa}$ s'jel ${ }^{\mathrm{PF}}$ jablok.
I ate apple.PL.GEN
'I ate some apples.' (Kagan 2013: 5)

In Croatian and Serbian, the case alternation is also possible with imperfective verbs (Reiter 1977: 358, Mendoza 2004: 229), which is exemplified by the Croatian example in (35). Furthermore, we can see that - according to Mendoza - the case alternation interacts with the definiteness of the direct object. It is claimed that the marking of the direct object with the accusative results in a definite reading of water in (35b) whereas the genitive case leads to an indefinite interpretation (35a). Such examples should be checked with Croatian native speakers once more in order to elucidate if really only a definite reading is possible in (35b) and if (35a) also allows a partitive reading.

(35) Croatian (Mendoza 2004: 229)
a. On pije ${ }^{\mathrm{IMPF}}$ vod- $y$.
he drink water-GEN
'He drinks water'
b. On pije vod $^{\mathrm{IMPF}} \mathrm{u}$
he drink water-ACC
'He drinks the water'

In Czech, the genitive object is obsolete and odd with the perfective verb vypit 'drink' (36a). This is at least true for Bohemian Czech, according to my work with my Czech informants in Prague. The combination of the imperfective verb pit 'drink' is not accepted (36b):

(36) Czech
a. ?Petr vy-pil ${ }^{\mathrm{PF}}$ vod- $y$.
Petr drink.PST water-SG.GEN
'Petr drank some water.'
b. $\quad{ }^{*}$ Petr pil ${ }^{\mathrm{IMPF}} \quad$ vod-y.
Petr drink.PST water-SG.GEN
'Petr drank some water.' 
There is also a general tendency in (Bohemian) Czech to avoid the genitive in other contexts such as with direct objects of negated sentences or the cases described in 5.3.1 (Janda \& Townsend 2000: 69, Franks \& Dziwirek 1993: 294f.).

In Upper Silesian, the direct object in the genitive case is accepted neither with perfective nor with imperfective incremental theme verbs $(37 \mathrm{~b}$, d). Furthermore, perfective incremental verbs cannot be combined with bare plural and mass nouns as they are not inherently quantized. The only interpretation of (37a) is a kind-denoting reading. The only combination possible is an imperfective verb and direct object in the accusative $(37 \mathrm{c}):^{23}$

\begin{tabular}{|c|c|c|}
\hline (37) & Perfective verb & Imperfective verb \\
\hline ACC & 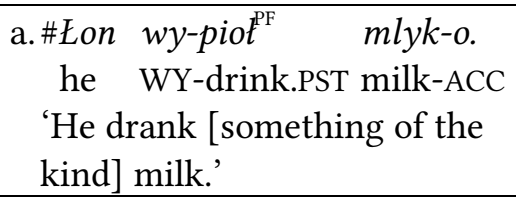 & $\begin{array}{l}\text { c. Łon piot }{ }^{\mathrm{IMF}} \text { mlyk-o. } \\
\text { he drink.PST milk-ACC } \\
\text { 'He drank/was drinking } \\
\text { milk.' }\end{array}$ \\
\hline GEN & $\begin{array}{cll}\text { b. }{ }^{*} \text { Łon } & \text { wy-pio }{ }^{\mathrm{PF}} & \text { mlyk-a. } \\
\text { he } & \text { WY-drink.PST milk-GEN }\end{array}$ & $\begin{array}{rll}\text { d. }{ }^{*} \text { Łon } & \text { piot }{ }^{\mathrm{MPF}} & \text { mlyk-a. } \\
\text { he } & \text { drink.PST } & \text { milk-GEN }\end{array}$ \\
\hline
\end{tabular}

The Slavic variation described above can be summarized in table 18 . From the top to the bottom, the languages allow for more contexts of fluid case alternations of bare direct objects with the incremental theme verbs eat and drink. Upper Silesian is most restrictive and does not allow a genitive object. Furthermore, perfective verbs cannot combine with all accusative direct objects, but only with those which are quantized either inherently as with singular count nouns or they must be quantized by a definite article with mass and plural nouns. In contrast, Czech always allows for a direct object of a perfective verb to be accusative. In Russian, a fluid case alternation can be observed with perfective verbs in contrast to Serbian and Croatian, which also show this pattern with imperfective verbs. For Bohemian Czech, the genitive object is regarded as odd by my informants. However, Filip (p.c.) emphasizes that this is only the case in Bohemian Czech whereas genitive objects are still acceptable in Moravia,

$\overline{23}$ For a more detailed analysis of Upper Silesian see Czardybon \& Fleischhauer (2014). 
especially Eastern Moravia so that we have a cline from West to East. In Polish, only accusative objects are acceptable for increasing numbers of speakers.

\begin{tabular}{|l|c|c|c|c|}
\hline & $\begin{array}{c}\text { IMPF }+ \\
\text { ACC }\end{array}$ & $\begin{array}{c}\text { PF }+ \\
\text { ACC }\end{array}$ & $\begin{array}{c}\text { PF }+ \\
\text { GEN }\end{array}$ & $\begin{array}{c}\text { IMPF }+ \\
\text { GEN }\end{array}$ \\
\hline Upper Silesian & + & $(+)$ & - & - \\
\hline Polish & + & + & $(+)$ & - \\
\hline (Bohemian) Czech & + & + & $(+)$ & - \\
\hline Russian & + & + & + & - \\
\hline Serbian/Croatian & + & + & + & + \\
\hline
\end{tabular}

Table 18: The distribution of the partitive genitive with eat and drink in the investigated Slavic languages.

The explanation for this variation must be left an open question. The fact that genitive objects are obsolete in Bohemian Czech fits into the general picture since the accusative is strongly preferred over the genitive in many other contexts in Czech (as has been illustrated in this chapter). This is, however, not the case in Polish where the genitive is obligatory in many other contexts. Why is it then falling out of use in this context? This question has to be left for future work.

\subsection{Conclusion}

In the previous section, I showed that the genitive has a (pseudo-)partitive function in Polish. The partitive genitive is restricted to mass and plural nouns as direct objects of some perfective verbs in Polish. The Polish data also reveal that the partitive genitive is often not accepted by the majority of my Polish informants. The partitive genitive leads to an indefinite interpretation of the direct object. I tried to extend my investigation by including concept types other than SNs. For this task, I chose the assumed FN skóra 'skin', which cannot be marked by the partitive genitive and the assumed RN krew 'blood' that has an indefinite interpretation as a genitive object. I could not find any INs 
which could enter the investigated construction with partitive genitive as well as the accusative case. The accusative direct object leads to a definite reading with the Polish verbs for eat and drink with SNs, RNs, and FNs. With the verbs of giving and taking, the accusative object can have a definite or indefinite interpretation depending on the context with sortal concepts. This shows that the accusative does not automatically lead to a definite interpretation as assumed by Sadziński (1977: 41, 1991: 155, 1995/96: 48f., 86). With the investigated relational and functional concepts only a definite interpretation is possible. This is summarized in table 19.

\begin{tabular}{|l|c|c|c|c|c|c|c|c|}
\hline & \multicolumn{3}{|c|}{ ACC } & \multicolumn{3}{c|}{ GEN } \\
\cline { 2 - 8 } & SN & RN & FN & IN & SN & RN & FN & IN \\
\hline $\begin{array}{l}\text { Perfective verbs } \\
\text { of giving and } \\
\text { taking }\end{array}$ & $\begin{array}{c}\text { def./ } \\
\text { indef. }\end{array}$ & def. & ? & (indef.) & $*$ & $?$ \\
\cline { 1 - 4 } $\begin{array}{l}\text { Perfective } \text { eat } \\
\text { and drink }\end{array}$ & def. & & & & & & \\
\hline
\end{tabular}

Table 19: Summary of the fluid case alternations in Polish and their interaction with definiteness.

Although the partitive genitive seems to be falling out of use in Polish, the genitive of negation is still obligatory. Table 20 summarizes the distribution of the genitive of negation and partitive genitive for the investigated Slavic languages. ${ }^{24}$ What can be observed is that the distribution of the genitive of negation on the one hand and the partitive genitive are independent of each other. One cannot predict that if a language marks direct object of negated sentences with the genitive then this language also has a partitive genitive, or vice versa. This is also supported by the Slovenian and Serbian/Croatian data.

$\overline{24}$ '++' stands for obligatory, '+' for optional, '(+)' for restricted, and '-' for no use. 


\begin{tabular}{|l|c|c|c|}
\hline & $\begin{array}{c}\text { Genitive of } \\
\text { negation }\end{array}$ & $\begin{array}{c}\text { Partitive genitive } \\
\text { with verbs of } \\
\text { giving and taking }\end{array}$ & $\begin{array}{c}\text { Partitive genitive } \\
\text { with the verbs } \\
\text { for eat } \text { and drink }\end{array}$ \\
\hline Bohemian Czech & - & $(+)$ & $(+)$ \\
\hline Slovenian & ++ & - & - \\
\hline Upper Silesian & ++ & $(+)$ & - \\
\hline Standard Polish & ++ & $(+)$ & $(+)$ \\
\hline Russian & + & + & + \\
\hline Serbian/Croatian & - & + & + \\
\hline
\end{tabular}

Table 20: Summary of the distribution of the genitive of negation and partitive genitive. 
